\title{
Structural Determination and Proposed Biosynthesis of Alcanivorone, a Novel $\alpha$-Pyrone Produced by Alcanivorax jadensis
}

\author{
Kaneo Kanoh, Kyoko Adachi, Atsuko Katsuta, Yoshikazu Shizuri
}

Received: August 16, 2007 / Accepted: February 7, 2008

(C) Japan Antibiotics Research Association

\begin{abstract}
A novel $\alpha$-pyrone designated as alcanivorone was found in a culture broth of the marine bacterium, Alcanivorax jadensis, and its structure was determined by an analysis of 1D NMR, 2D NMR and MS data. Alcanivorone was produced by $A$. jadensis only when sodium pyruvate was added to the culture medium as a carbon source. Incorporation experiments using stable isotope-labeled pyruvate indicated that alcanivorone was biosynthesized from four molecules of pyruvate.
\end{abstract}

Keywords marine bacterium, Alcanivorax jadensis, $\alpha$-pyrone, pyruvic acid, biosynthesis

\section{Introduction}

Marine microorganisms have gained considerable attention as an important source of novel secondary metabolites [1]. Strains of the Alcanivorax group were first isolated from the North Sea as biosurfactant-producing and alkanedegrading marine bacteria, and have also been found in a variety of marine environments including oil spillcontaminated sites $[2,3]$. These strains have been shown to be important for the biodegradation of petroleum hydrocarbons in a marine environment, especially under bioremediation conditions [4]. During a series of investigations of new metabolites from marine microorganisms $[5,6]$, we found a novel $\alpha$-pyrone, alcanivorone (1), from the culture broth of $A$. jadensis (former name: Fundibacter jadensis [7]). We describe in this paper the production, structural determination,

K. Kanoh (corresponding author), K. Adachi, A. Katsuta, Y. Shizuri: Marine Biotechnology Institute Co. Ltd., 3-75-1 Heita, Kamaishi, Iwate 026-0001, Japan, E-mail: kaneo.kanoh@mbio.jp incorporation experiments with stable isotope-labeled sodium pyruvate, and a proposed biogenesis of $\mathbf{1}$ based on the incorporation experiments.



Alcanivorone (1)

\section{Materials and Methods}

\section{Strains}

Alcanivorax jadensis $\mathrm{T}^{\mathrm{T}}$ (DSM $12178^{\mathrm{T}}$ ) was obtained from Deutsche Sammlung von Mikroorganismen und Zellkulturen (DSMZ). Other Alcanivorax sp. bacteria, MBIC04549, MBIC04556 and MBIC05570, were isolated from seawater in Heita Bay, Kamaishi, Japan. They were maintained on Marine Agar 2216 (Difco).

\section{Fermentation and Isolation}

The NSW medium contained the following components (for 1.0 liter): $1.0 \mathrm{~g}$ of ammonium nitrate, $0.2 \mathrm{~g}$ of dipotassium hydrogenphosphate, $0.02 \mathrm{~g}$ of iron(III) citrate $n$-hydrate, $800 \mathrm{ml}$ of filtered natural seawater, and $200 \mathrm{ml}$ of distilled water at $\mathrm{pH} 7.6$ before autoclaving; an appropriate carbon source, i.e., sodium pyruvate, sodium acetate, glucose or hexadecane, was added according to need. The NSW medium supplemented with $5.0 \mathrm{~g} /$ liter of sodium pyruvate (NSW $+0.5 \%$ sodium pyruvate) was used for the production of 1 . The seed culture was cultured in $50 \mathrm{ml}$ of 
1/10 Marine Broth $(1 / 10 \mathrm{MB})$ at $30^{\circ} \mathrm{C}$ with rotary shaking at $100 \mathrm{rpm}$ for 5 days. The composition of $1 / 10 \mathrm{MB}$ (for 1.0 liter) is as follows; $3.74 \mathrm{~g}$ of Marine Broth 2216 (Difco), $750 \mathrm{ml}$ of filtered natural seawater and $200 \mathrm{ml}$ of distilled water at $\mathrm{pH} 7.6$ before autoclaving. A 10-ml amount of the seed culture was inoculated into 1.0 liter of NSW $+0.5 \%$ sodium pyruvate in a 3-liter Erlenmeyer flask. Fermentation was carried out at $30^{\circ} \mathrm{C}$ with rotary shaking at $100 \mathrm{rpm}$ for 10 days. The fermentation broth (4.0 liters total) was centrifuged at $12,000 \mathrm{~g}$ for 20 minutes, and the supernatant was extracted twice with an equal volume of EtOAc at $\mathrm{pH}$ 2. The precipitate was extracted with $\mathrm{CHCl}_{3} / \mathrm{MeOH}(9: 1)$. Both organic extracts were mixed and concentrated in vacuo, before being applied to a silica gel column and eluted with $\mathrm{CHCl}_{3} / \mathrm{MeOH} / \mathrm{AcOH}$ $(90: 10: 0.5)$. The 1-containing fractions were gathered and further purified by HPLC under the following conditions: column, COSMOSIL ${ }^{\circledR} 5$ C 18 -AR $(10 \times 250 \mathrm{~mm}$, Nacalai Tesque, Kyoto, Japan); flow rate, $2.0 \mathrm{ml} /$ minute; solvent system, a linear gradient from $50 \% \mathrm{MeOH}-\mathrm{H}_{2} \mathrm{O}$ containing $0.05 \%$ phosphoric acid to $100 \% \mathrm{MeOH}$ containing $0.05 \%$ phosphoric acid in 30 minutes; detection, UV $\lambda 250 \mathrm{~nm}$. The HPLC purification was conducted twice to give $\mathbf{1}$ $(7.3 \mathrm{mg})$ as a white powder. The physico-chemical properties of $\mathbf{1}$ were as follows: molecular formula, $\mathrm{C}_{10} \mathrm{H}_{10} \mathrm{O}_{5}$; molecular weight, 210; ESI-MS: positive $m / z 211(\mathrm{M}+\mathrm{H})^{+}$, negative $\mathrm{m} / \mathrm{z} 209(\mathrm{M}-\mathrm{H})^{-}$; HRFAB-MS: positive $\mathrm{m} / \mathrm{z}$ found $211.0606(\mathrm{M}+\mathrm{H})^{+}$, calcd. 211.0607 (for $\mathrm{C}_{10} \mathrm{H}_{11} \mathrm{O}_{5}$ ); $\mathrm{UV}(\mathrm{MeOH}) \lambda_{\max } \mathrm{nm}(\varepsilon), 262(11,000) ; \mathrm{IR} v_{\max }(\mathrm{KBr})$ $\mathrm{cm}^{-1}: 2929,2608,2361,2339,1697,1521,1458,1419$, 1335.

\section{Spectroscopic Measurements}

UV and IR spectra were respectively recorded by Beckman DU640 and Jasco FT/IR-430 infrared spectrometers. FABMS and HRFAB-MS were recorded by a Jeol JMS-SX 120 instrument. ${ }^{1} \mathrm{H}-\mathrm{NMR}$ and all $2 \mathrm{D}$ NMR spectra were measured by a Varian Unity INOVA 750 spectrometer, and the ${ }^{13} \mathrm{C}-\mathrm{NMR}$ spectrum was measured by a Varian Unity INOVA 500 spectrometer. Chemical shifts are referenced to the solvent peaks of $\delta_{\mathrm{H}} 3.31$ and $\delta_{\mathrm{C}} 49.15$ for $\mathrm{CD}_{3} \mathrm{OD}$.

\section{Antimicrobial Activity}

The antimicrobial activity of $\mathbf{1}$ was measured by the paper disk method. $\mathrm{A} \mathrm{MeOH}$ soln of a sample was dropped on to a paper disk ( $6 \mathrm{~mm}$ in diameter), and the disk was dried for 30 minutes in a clean enclosure. The sample amount was $5.0 \mathrm{mg} / \mathrm{disk}$. The disk was then put on an agar medium that had been inoculated with each test microorganism, using Escherichia coli IFO 3301, Bacillus subtilis IFO 3134, Staphylococcus aureus IFO 12732, Salinivibrio costicola
ATCC 33508, and Candida albicans IFO 1060. Halo formation was observed after 48 hours of incubation at $30^{\circ} \mathrm{C}$.

\section{Feeding Experiment}

Sodium $\left[2-{ }^{13} \mathrm{C}\right]$ pyruvate, sodium $\left[1,2-{ }^{13} \mathrm{C}_{2}\right]$ pyruvate and sodium $\left[2,3-{ }^{13} \mathrm{C}_{2}\right]$ pyruvate were purchased from Sigma Chemical Co., USA. The seed culture was cultured for 5 days in $20 \mathrm{ml}$ of $1 / 10 \mathrm{MB}$ at $30^{\circ} \mathrm{C}$ with rotary shaking at $100 \mathrm{rpm}$. A $1-\mathrm{ml}$ amount of the seed culture was inoculated into $100 \mathrm{ml}$ of $\mathrm{NSW}+0.5 \%$ sodium pyruvate, $450 \mathrm{mg}$ of sodium pyruvate and $50 \mathrm{mg}$ of sodium $\left[1,2-{ }^{13} \mathrm{C}_{2}\right]$ pyruvate in a 300-ml Erlenmeyer flask, and then cultured for 10 days at $30^{\circ} \mathrm{C}$ with rotary shaking at $100 \mathrm{rpm}$. The cultured broth was extracted and separated by silica gel column chromatography, before being purified by HPLC as already described. A 1.3-mg amount of labeled 1 was obtained from the 100-ml culture.

The sodium $\left[2-{ }^{13} \mathrm{C}\right]$ pyruvate and sodium $\left[2,3-{ }^{13} \mathrm{C}_{2}\right]$ pyruvate feeding experiments were performed by the same procedure as that just described for the sodium $\left[1,2-{ }^{13} \mathrm{C}_{2}\right]$ pyruvate feeding experiment. A $0.9-\mathrm{mg}$ amount of labeled 1 was obtained from the sodium $\left[2-{ }^{13} \mathrm{C}\right]$ pyruvate feeding experiment, and a $0.6 \mathrm{mg}$ from the sodium $\left[2,3-{ }^{13} \mathrm{C}_{2}\right]$ pyruvate feeding experiment.

\section{Results and Discussion}

\section{Production of 1 by $A$. jadensis}

The effect of carbon source, using sodium pyruvate, sodium acetate, sodium propionate, glucose and hexadecane, on the production of $\mathbf{1}$ was investigated. Each carbon source was added to the NSW medium at a concentration of $0.5 \%$ $(\mathrm{w} / \mathrm{v})$. The production of $\mathbf{1}$ was only detected $(12.4 \mathrm{mg} / \mathrm{liter})$ when sodium pyruvate was used as the carbon source. The addition of the other carbon sources, sodium acetate, sodium propionate, or hexadecane did not produce $\mathbf{1}$, although the growth of the producing bacterium was almost comparable to the growth by pyruvate. A. jadensis didn't grow when glucose was added as a carbon source and didn't produce $\mathbf{1}$.

As well as A. jadensis, the other Alcanivorax strains, MBIC04549, MBIC04556 and MBIC05570, also produced 1 with the addition of sodium pyruvate at a similar level of productivity: $10.0,9.0$ and $8.4 \mathrm{mg} /$ liter, respectively.

\section{Structural Elucidation}

The molecular formula of $\mathbf{1}$ was determined to be $\mathrm{C}_{10} \mathrm{H}_{10} \mathrm{O}_{5}$ by high-resolution FAB-MS [measured, 211.0606; calcd., 211.0607 for $\left.(\mathrm{M}+\mathrm{H})^{+}\right]$. In the ${ }^{13} \mathrm{C}-\mathrm{NMR}$ spectrum, ten 
carbon signals, including two carbonyl carbons $(\delta 172.43$ and $\delta 162.02)$, six olefinic carbons $(\delta 157.66, \delta 143.84, \delta$ $130.59, \delta 125.59, \delta 120.24$, and $\delta 120.30)$ and two methyl carbons ( $\delta 21.99$ and $\delta 12.31)$ were observed. In the ${ }^{1} \mathrm{H}-$ NMR spectrum, only four kinds of proton signals indicating two methyl protons ( $\delta 2.37$ and $\delta 2.07)$ and two olefin protons ( $\delta 7.40$ and $\delta 6.47$ ) were observed. All direct connections between the carbons and protons were determined by HSQC. Long-range coupling was observed between the methyl proton $\left(2^{\prime}-\mathrm{CH}_{3}: \delta 2.07 ; 3 \mathrm{H}\right.$, d, $J=1.5 \mathrm{~Hz})$ and the olefinic proton $\left(\mathrm{H}-3^{\prime}: \delta 6.47 ; 1 \mathrm{H}, \mathrm{d}\right.$, $J=1.5 \mathrm{~Hz}$ ), and $\mathrm{HMBC}$ signals between $2^{\prime}-\mathrm{CH}_{3}$ and $\mathrm{C}-1^{\prime}$, and $\mathrm{H}-3^{\prime}$ and $\mathrm{C}-1^{\prime}$ were observed. A 2-methylacrylic acid moiety was determined by these signals, and the NOE signal between $\mathrm{H}-3^{\prime}$ and $2^{\prime}-\mathrm{CH}_{3}$ indicating the stereochemistry of the double bond $\left(\mathrm{C}-2^{\prime}=\mathrm{C}-3^{\prime}\right)$ to be $Z$. A 3 -hydroxy-6-methyl- $\alpha$-pyrone moiety was determined from $\mathrm{HMBC}$ signals from $4-\mathrm{H}$ and from $6-\mathrm{CH}_{3}$ as shown in Fig. 1. The connection of the acrylic acid moiety and the $\alpha$ pyrone moiety was determined by HMBC signals between $\mathrm{H}-3^{\prime}$ and $\mathrm{C}-4$, and $\mathrm{H}-3^{\prime}$ and $\mathrm{C}-6 . \mathbf{1}$ is a new $\alpha$-pyrone type metabolite, its NMR data being summarized in Table 1.

\section{Antimicrobial Activity}

The antimicrobial activity of $\mathbf{1}$ was evaluated by the paper disk method (5.0 mg/disk). 1 exhibited mild antimicrobial activity, the halo diameter being $8 \mathrm{~mm}$ for Bacillus subtilis IFO 3134, $7 \mathrm{~mm}$ for Staphylococcus aureus IFO 12732, and $22 \mathrm{~mm}$ for Salinivibrio costicola ATCC 33508, but no inhibitory activity was observed against these three strains in liquid culture assay up to $200 \mathrm{ppm}$ (MIC $>200 \mathrm{ppm}$ ). No inhibitory activity was apparent toward Escherichia coli IFO 3301 and Candida albicans IFO 1060 by the paper disk method.

\section{Feeding Experiment and Biosynthetic Pathway of 1}

A feeding experiment was carried out with sodium $\left[2-{ }^{13} \mathrm{C}\right]$ pyruvate. ${ }^{13} \mathrm{C}-\mathrm{NMR}$ data for the labeled compound indicated that signal intensities of C-3, C-5, C-6 and C-2' were clearly higher than those of the non-labeled compound (Table 1). The results indicate that these carbons (C-3, C-5, C-6 and $\mathrm{C}-2^{\prime}$ ) originated from the $\mathrm{C}-2$ carbon of pyruvate. A feeding experiment with sodium $\left[1,2-{ }^{13} \mathrm{C}_{2}\right]$ pyruvate was carried out. The signal intensities of C-2, C-3, C-5, C-6, C$1^{\prime}$ and $\mathrm{C}-2^{\prime}$ were all higher than those of the non-labeled compound, and ${ }^{13} \mathrm{C}^{-13} \mathrm{C}$ coupling of C-2-C-3 $\left(J_{\mathrm{CC}}=94 \mathrm{~Hz}\right)$ and $\mathrm{C}-1^{\prime}-\mathrm{C}-2$ ' $\left(J_{\mathrm{CC}}=69 \mathrm{~Hz}\right)$ was observed (Table 1). These results indicate that $\mathrm{C}-2$ and $\mathrm{C}-3$ originated from a single

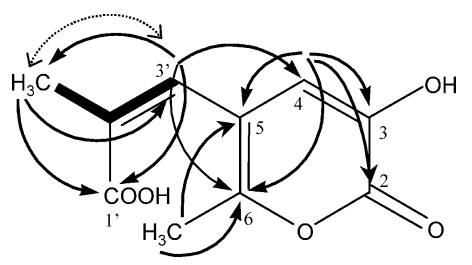

Fig. 1 Structural elucidation of $\mathbf{1}$ by HMBC.

Bold lines reveal spin systems observed in COSY, and arrows reveal HMBC signals. An HMBC signal between $\mathrm{H}-4$ and $\mathrm{C}-2$ was observed in the measurement used DMSO- $d_{6}$ as a solvent. The dotted arrow reveals an NOE signal.

Table 1 NMR data for 1 (750 MHz for ${ }^{1} \mathrm{H}, 125 \mathrm{MHz}$ for ${ }^{13} \mathrm{C}, \mathrm{CD}_{3} \mathrm{OD}$ ) and summary of the feeding experiments

\begin{tabular}{|c|c|c|c|c|c|c|c|}
\hline \multirow{2}{*}{ Position } & \multirow{2}{*}{$\delta^{1} \mathrm{H}(\mathrm{ppm})$} & \multirow{2}{*}{$\begin{array}{c}\delta^{13} \mathrm{C} \\
\text { (ppm) }\end{array}$} & \multicolumn{5}{|c|}{ Specific incorporation (relative intensity to nonlabeled $\mathbf{1}$ ) } \\
\hline & & & {$\left[2-{ }^{13} \mathrm{C}\right]$ pyruvate ${ }^{\mathrm{a}}$} & {$\left[1,2-{ }^{13} \mathrm{C}\right]$ pyruvate $e^{\mathrm{a}, \mathrm{c}}$} & $J_{\mathrm{CC}}(\mathrm{Hz})$ & {$\left[2,3^{13} \mathrm{C}\right]$ pyruvate ${ }^{b, c}$} & $J_{C C}(H z)$ \\
\hline 2 & & 162.02 & 0.8 & $9.4^{*}$ & 94 & $1^{\mathrm{b}}$ & \\
\hline 3 & & 143.84 & $12.8^{*}$ & $10.6^{*}$ & 94 & $6.7^{*}$ & 70 \\
\hline 4 & $7.40(1 \mathrm{H}, \mathrm{s})$ & 120.30 & 1.1 & 1.1 & & $9.4^{*}$ & 70 \\
\hline 5 & & 120.24 & $11.5^{*}$ & $9.6^{*}$ & & $17.7^{*}$ & 63 \\
\hline 6 & & 157.66 & $11.0^{*}$ & $10.6^{*}$ & & $6.1^{*}$ & 54 \\
\hline $6-\mathrm{CH}_{3}$ & $2.37(3 \mathrm{H}, \mathrm{s})$ & 12.31 & $1^{\mathrm{a}}$ & $1^{\mathrm{a}}$ & & $19.4^{*}$ & 54 \\
\hline $1^{\prime}$ & & 172.43 & 1.6 & $11.5^{*}$ & 69 & 1.1 & \\
\hline $2^{\prime}$ & & 130.59 & $15.2^{*}$ & $11.5^{*}$ & 69 & $10.5^{*}$ & 44 \\
\hline $2^{\prime}-\mathrm{CH}_{3}$ & $2.07(3 \mathrm{H}, \mathrm{d}, J=1.5 \mathrm{~Hz})$ & 21.99 & 1.1 & 0.9 & & $21.1^{*}$ & 44 \\
\hline $3^{\prime}$ & $6.47(1 \mathrm{H}, \mathrm{d}, J=1.5 \mathrm{~Hz})$ & 125.09 & 0.9 & 0.9 & & $6.3^{*}$ & 63 \\
\hline
\end{tabular}

\footnotetext{
a Relative enrichment were normalized to the peak intencity of the $6-\mathrm{CH}_{3}$ signal.

${ }^{b}$ Relative enrichment were normalized to the peak intencity of the $\mathrm{C}-2$ signal.

${ }^{c}$ For the splitted signals, a sum of intencities of splitted peaks was used.

* Enriched signal.
} 
A)



B)
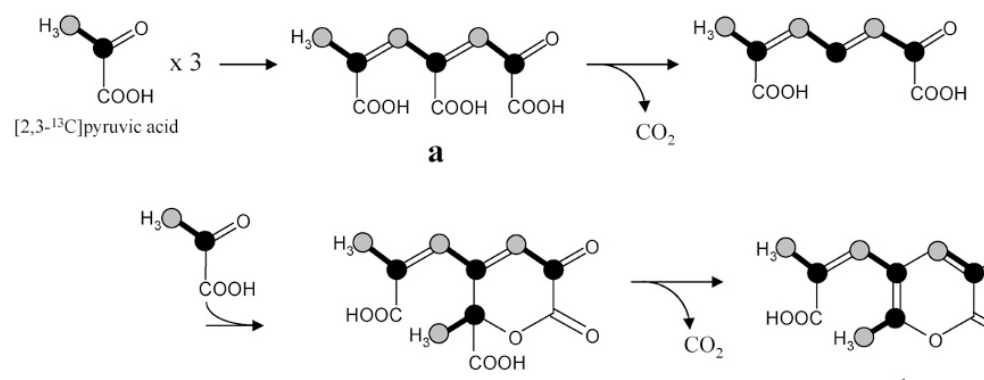

b

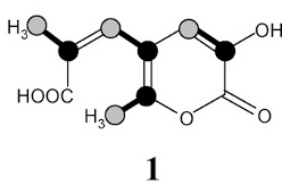

Fig. 2 Hypothetical biosynthetic pathway for 1.

-, 0 and $\bigcirc$ : C-1, C-2 and C-3 in pyruvic acid, respectively.

molecule of pyruvate, and that $\mathrm{C}-1^{\prime}$ and $\mathrm{C}-2^{\prime}$ were also from a single molecule. The signal intensities of C-5 and C-6 were clearly increased, but no vicinal C-C coupling was apparent. These results indicate that the incorporated two moles of pyruvate were decarboxylated during biosynthesis. We therefore propose the biosynthetic pathway shown in Fig. 2A. The first step may be the condensation of three moles of pyruvate to form $\mathbf{a}$, and then decarboxylation and condensation with another pyruvate, and successive lactone formation to afford $\mathbf{b}$. The second decarboxylation from $\mathbf{b}$ gave natural compound $\mathbf{1}$. The incorporation pattern of $\left[1,2-{ }^{13} \mathrm{C}_{2}\right]$ pyruvate into $\mathbf{1}$ is shown in Fig. 2A.

To clarify the origin of $2^{\prime}-\mathrm{CH}_{3}$ and $6-\mathrm{CH}_{3}$ and confirm the proposed biosynthesis shown in Fig. 2A, the feeding experiment with sodium $\left[2,3-{ }^{13} \mathrm{C}_{2}\right]$ pyruvate was also carried out. The signal intensities of C-3, C-4, C-5, C-6, $6-\mathrm{CH}_{3}, \mathrm{C}-2^{\prime} 2^{\prime}-\mathrm{CH}_{3}$, and $\mathrm{C}-3^{\prime}$ were higher than those of the non-labeled compound, and ${ }^{13} \mathrm{C}^{-13} \mathrm{C}$ coupling of $\mathrm{C}$ $3-\mathrm{C}-4\left(J_{\mathrm{CC}}=70 \mathrm{~Hz}\right), \mathrm{C}-5-\mathrm{C}-3^{\prime}\left(J_{\mathrm{CC}}=63 \mathrm{~Hz}\right), \mathrm{C}-6-6-\mathrm{CH}_{3}$ $\left(J_{\mathrm{CC}}=54 \mathrm{~Hz}\right)$, and $\mathrm{C}-2^{\prime}-2^{\prime}-\mathrm{CH}_{3}\left(J_{\mathrm{CC}}=44 \mathrm{~Hz}\right)$ was observed (Table 1). These results indicated that $6-\mathrm{CH}_{3}$ and $2^{\prime}-\mathrm{CH}_{3}$ were also from pyruvate, and the incorporation pattern of [2,3- $\left.{ }^{13} \mathrm{C}_{2}\right]$ pyruvate into $\mathbf{1}$ is shown in Fig. $2 \mathrm{~B}$, supporting the proposed biosynthesis of $\mathbf{1}$. The other carbon sources including acetate, propionate, hexadecane and glucose did not produce $\mathbf{1}$. We also investigated the incorporation of a methyl ${ }^{13} \mathrm{C}$-methionine, but no incorporation was observed (data not shown), suggesting that pyruvate was the sole carbon source to produce 1 .

It is very interesting that marine bacteria, Alcanivorax species, biosynthesized novel $\alpha$-pyrone, 1 using only pyruvate via proposed pathway shown in Fig. 2, being completely different from polyketide biosynthesis. Molecular cloning and biochemical approaches would clarify this unique biosynthetic mechanism in Alcanivorax species.

Acknowledgement We thank Dr. Y. Kobayashi for the HRFABMS measurements.

\section{References}

1. Blunt JW, Copp BR, Murano MHG, Northcote PT, Prisep MR. Marine natural products. Nat Prod Rep 21: 1-49 (2004)

2. Yakimov MM, Golysin PN, Lang S, Moore ER, Abraham WR, Lunsdorf H, Timmis KN. Alcanivorax borkumensis gen. nov., sp. nov., a new, hydrocarbon-degrading and surfactant-producing marine bacterium. Int J Syst Bacteriol 48: 339-348 (1998)

3. Abraham WR, Meyer H, Yakimov M. Novel glycinecontaining glucolipids from the alkane using bacterium Alcanivorax borkumensis. Biochim Biophys Acta 1393: 57-62 (1998)

4. Harayama S, Kishira H, Kasai Y, Shutsubo K. Petroleum 
biodegradation in marine environments. J Mol Microbiol Biotechnol 1: 63-70 (1999)

5. Jang JH, Kanoh K, Adachi K, Shizuri Y. Awajanomycin, a cytotoxic $\gamma$-lactone- $\delta$-lactam metabolite from marinederived Acremonium sp. AWA16-1. J Nat Prod 69: 1358-1360 (2006)

6. Kanoh K, Matsuo Y, Adachi K, Imagawa H, Nishizawa M, Shizuri Y. Mechercharstatin A and B, cytotoxic substances from marine derived Thermoactinomyces sp. YM3-251. J
Antibiot 58: 289-292 (2005)

7. Fernandes-Martinez J, Pujalte MJ, Garcia-Martinez J, Mata M, Garay E, Rodriguez-Valera F. Description of Alcanivorax venustensis sp. nov. and reclassification of Fundibacter jadensis DSM $12178 \mathrm{~T}$ (Bruns and Berthe-Corti 1999) as Alcanivorax jadensis comb. nov., members of the emended genus Alcanivorax. Int J Syst Evol Microbiol 53: 331-338 (2003) 